\title{
DOI 10.26886/2520-7474.3(35)2019.3
}

\section{UDC 911.3}

\section{MIGRATION PROCESSES}

\section{«UKRAINE-POLAND»: SPECIFICATION AND CONSEQUENCES}

\section{Shevchuk, Doctor of Economical Sciences, Professor}

Uniwersytet Jana Kochanowskiego, Poland, Kielce
A. Shevchuk, Doctor of Economical Sciences
Cherkassy State Technological University, Ukraine, Cherkassy
G. Labinska, Phd of Geographical Sciences
Lviv Ivan Franko National University, Ukraine, Lviv

The analysis of the specificity and assessment of the consequences of the migration processes "Ukraine - Poland" the article was devoted. The relevance of the topic is revealed due to the emphasis on the needs of the global labor market, which caused massive displacement of people migration tsunami and exacerbated the problem of deportation of both countries in the near future. The analysis is based on the use of Eurostat and other official sources. The progress of negative demographic tendencies in Ukraine, which differ on the background of similar processes in Poland was revealed. The emphasis is on positive results of the demographic policy of the Polish government, which takes into account the significant contribution of Ukrainian workers. This eventually ensured a stable economic development of the country. At the same time, the outflow of highly educated specialists from Ukraine has led to a weakening of its economy. The outflow of Ukrainian students weakened the education system of Ukraine, contributing to the strengthening of the education system in Poland. The improvement of this situation in Ukraine is in implementation of a system of economic measures that would contribute to 
the settlement of Ukraine-Poland migration flows on a mutually beneficial basis for both countries.

Key words: demographic processes, demographic tsunami, specificity and motivation of migration processes, consequences of demographic processes, forecast.

Relevance of research topic. The massive displacement of people is one of the specific features of the XXI century with the formation of a series of migration tsunami towards the countries of the European Union. The "Ukraine-Poland" migration processes are remarkably distinct on this background, which in the last decade formed a powerful wave of migration tsunami. These processes will intensify due to the military situation and the growth of tensions on the eastern borders of Ukraine. Confirmation of this is the reorientation of migrant labor flows from the eastern to the western European vector. The introduction of a visa-free regime between Ukraine and the EU will contribute to the increase of the Ukraine-Poland migration flows and further increase of the Ukrainians poverty. Poland needs the Ukrainian labor force due to its own unfavorable demographic trends according to demographers to prevent Poland from being deserted by 2050 should be more than 5 million arriving here. The specifics and consequences of demographic processes "Ukraine-Poland" should always be in the sight of not only economists, sociologists, geographers, demographers and other scientists and also politicians and managers.

Analysis of recent research. Interpretation of the essence and features of the society and migration tsunami has intensified since the beginning of the twenty-first century [1]. Demographic processes are actively studied by Ukrainian scholarly schools in Kyiv under the guidance of academic Ella Libanova [2]. The solid research on Ukrainian migration 
and the formation of a migration policy made by Elena Malinovskaya [3], Ulyana Sadova and others.

Ukrainian migration processes are focusing on numerous interdisciplinary studies while remaining active subjects of international labour migration: the study of the volumes of migration flows abroad, their gender, age, educational and qualification structure, the amounts of earnings money and their purposes, etc. A thorough investigation of the new wave of Ukrainian migrants in Poland was conducted by Narodowy Bank Polski [4]. Polish scientists track the state of their labor market, its needs, and immigration policy with achieving maximum benefits for the state. The problem is also substantially updated by the imminent liberalization of the German labor market: the export-oriented economy of Germany experienced a man-made famine, and with the levels of remuneration existing in this country, it is not difficult to predict their attractiveness for migrant workers. Vitaliy Shapran [5] foresees the implementation of Polish experience when an employer can quickly help his foreign worker obtain a work permit, which is estimated to attract at least 0.5 million Ukrainians, especially those already working in Poland, and this problem requires constant monitoring.

The purpose of the article is to analyze the specifics and consequences of Ukraine-Poland migration processes in the context of the trends of demographic development of both countries and the challenges of the global labor market.

Presentation of the main research material. More than 42 million people live now in Ukraine, and more than 36 million live in Poland. The indicator of the average population density of Ukraine is twice smaller than Polish, and the area of Ukraine is almost twice larger. The problem of depopulation is now sharper in front of Ukraine. The confirmation of this 
conclusion is the dynamics of the indicator of population decline in the Ukraine.

Both countries characterize rather unfortunate demographic forecasts (Table 1). The countries of Eastern Europe are characterized by similar tendencies of the population, but in case of Ukraine they are especially striking. According to the first variant of the forecast [6], the reduction of the population of Ukraine was predicted by $48 \%$ [7].

The analysis of the results of the Forecast of the Development of Productive Forces, published in 1998, and subsequent comparison with real indicators, reflected the realism of the pessimistic version of the forecast for components of the movement of the population and the unpredictability of its migration activity by scale and direction (Table 2 ).

Table 1

\section{Projected changes in the population of certain European countries} for the period from 2010 to 2100

\begin{tabular}{|c|c|c|c|c|c|c|c|c|c|}
\hline \multirow[t]{2}{*}{ Countries } & \multicolumn{3}{|c|}{$\begin{array}{l}\text { Size of population per } \\
\text { year, million people }\end{array}$} & \multicolumn{2}{|c|}{$\begin{array}{c}\text { Indicator } \\
\text { difference } \\
2010-2100\end{array}$} & \multicolumn{4}{|c|}{$\begin{array}{l}\text { Corrected forecast data } \\
\text { size of population per year, } \\
\text { million people }\end{array}$} \\
\hline & 2010 & 2050 & 2100 & $\begin{array}{l}\text { у млн. } \\
\text { осіб }\end{array}$ & $y \%$ & 2017 & 2030 & 2050 & 2100 \\
\hline Austria & 8,4 & 7,3 & 6,2 & $-2,2$ & $-26,2$ & 8,7 & 8,9 & 8,8 & 8,2 \\
\hline Belarus & 9,5 & 7,5 & 5,7 & $-3,8$ & $-40,0$ & 9,5 & 9,2 & 8,6 & 7,6 \\
\hline UK & 62,0 & 66,2 & 64,4 & 2,4 & 3,9 & 66,2 & 70,6 & 75,4 & 80,9 \\
\hline Hungary & 10,0 & 7,6 & 6,2 & $-3,8$ & $-38,0$ & 9,7 & 9,2 & 8,3 & 6,4 \\
\hline Germany & 81,6 & 79,1 & 73,1 & $-8,5$ & $-10,4$ & 82,1 & 82,2 & 79,2 & 71,0 \\
\hline Spain & 43,5 & 37,3 & 34,1 & $-9,1$ & $-21,6$ & 46,4 & 46,1 & 44,4 & 36,4 \\
\hline Lithuania & 3,3 & 2,5 & 2,4 & $-0,9$ & $-27,3$ & 2,9 & 2,7 & 2,4 & 1,9 \\
\hline Netherlands & 16,6 & 16,9 & 15,9 & $-0,7$ & $-4,2$ & 17,0 & 17,6 & 17,5 & 16,5 \\
\hline Poland & 38,2 & 38,0 & 26,1 & $-12,1$ & $-31,7$ & 38,2 & 36,6 & 32,4 & 21,2 \\
\hline Portugal & 10,6 & 9,0 & 7,3 & $-3,3$ & $-31,1$ & 10,3 & 9,9 & 8,9 & 6,6 \\
\hline Romania & 21,5 & 18,1 & 14,8 & $-6,7$ & $-31,2$ & 19,7 & 18,5 & 16,4 & 12,1 \\
\hline Slovakia & 5,5 & 4,9 & 4,0 & $-1,5$ & $-27,2$ & 5,4 & 5,3 & 4,9 & 3,8 \\
\hline Ukraine & 45,9 & 31,8 & 24,1 & $-21,8$ & $-47,5$ & 44,2 & 41,2 & 36,4 & 28,2 \\
\hline France & 62,9 & 64,2 & 60,2 & $-2,7$ & $-4,3$ & 64,9 & 67,9 & 70,6 & 74,2 \\
\hline $\begin{array}{l}\text { Czech } \\
\text { Republic }\end{array}$ & 10,5 & 8,6 & 6,7 & $-3,8$ & $-36,1$ & 10,6 & 10,5 & 10,1 & 8,9 \\
\hline
\end{tabular}

Source: $[6,7]$. 


\section{Comparison of projected and real indicators of demographic} development of Ukraine, according to the "Forecast of the development of productive forces of 1998"

\begin{tabular}{|l|c|c|c|c|c|}
\hline & 1998 & 2000 & 2005 & 2010 & 2015 \\
\hline \multicolumn{4}{|c|}{ Pessimistic forecast } \\
\hline $\begin{array}{l}\text { Total fertility rate, number of live } \\
\text { births per 1000 women }\end{array}$ & 1,26 & 1,16 & 1,32 & 1,50 & 1,48 \\
\hline $\begin{array}{l}\text { Average life expectancy of men, } \\
\text { years }\end{array}$ & 62,43 & 62,85 & 63,55 & 64,22 & 66,75 \\
\hline $\begin{array}{l}\text { Average life expectancy of } \\
\text { women, years }\end{array}$ & 73,34 & 73,52 & 73,98 & 74,47 & 76,31 \\
\hline Migration balance, thsd. persons & -134 & -174 & -192 & -211 & -225 \\
\hline All population, persons & $\mathbf{5 0 2 4 5 , 2}$ & $\mathbf{4 9 3 6 1 , 5}$ & $\mathbf{4 6 7 5 7 , 9}$ & $\mathbf{4 4 7 5 2 , 9}$ & $\mathbf{4 3 2 2 0 , 5}$ \\
\hline \multicolumn{7}{|l|}{ Realistic figures } & & \\
\hline $\begin{array}{l}\text { Total fertility rate, the number of } \\
\text { live births per 1000 women }\end{array}$ & 1,21 & 1,12 & 1,21 & 1,44 & 1,51 \\
\hline $\begin{array}{l}\text { Average life expectancy of men, } \\
\text { years }\end{array}$ & 63,17 & 62,10 & 62,23 & 65,28 & 66,37 \\
\hline $\begin{array}{l}\text { Average life expectancy of } \\
\text { women, years }\end{array}$ & 73,84 & 73,53 & 73,97 & 75,50 & 76,25 \\
\hline $\begin{array}{l}\text { Migration balance, thsd. persons } \\
\text { All population, persons }\end{array}$ & $-152,0$ & $-133,6$ & 4,6 & 16,1 & 14,2 \\
\hline
\end{tabular}

Source: [8].

Most likely, the population of Ukraine over the next 50 years will decline with a rapid trends, as the country's demographic potential has been significantly lost [2]. Scientists recommend the involvement of limited immigrant groups in the context of the intensification of immigration policy, which will ensure a slowdown in the rate of depopulation, and will allow a more or less acceptable ratio between taxpayers and those in state retention.

Poland is actively implementing the tactics of facilitating the immigration of able-bodied Ukrainians into their territories relying on available demographic forecasts and the growing demand for labor in the face of its scarcity.

Mass displacement of population between Ukraine and Poland is due to geography, history, the presence of national minorities on both sides of 
the border, cultural and linguistic affinity, family ties, developed transport links, etc.

The main motivation for crossing the border, of course, is economic. An indicator of economic development is the size of the average salary. It is 5.3 times smaller in Ukraine. The official salary in Poland by the employment sector has the following size: the IT sphere - 720-2582 $€$; the sphere of construction - 480-800 $€$; the sphere of hotel and restaurant business - 430$520 €$; unskilled workers - 460-600 €; agriculture - 453-780 €; seasonal work - 430-800 $€[9]$.

Earned money is spent by laborers on current needs or on improving the housing situation in Ukraine. One third of the Ukrainians earning are spent in the country of employment. So, in 2015, Ukrainians earned PLN 8 billion (about UAH 57 billion) in Poland, and 63\% of them were transferred to Ukraine. Most often migrants transfer money to the own houses personally. The average value of one transfer is 1800 PLN every 2-3 months, slightly more than $13 \%$ of the workers transfer the amount of 5 thousand PLN. 43\% of Ukrainians converts before the transfer PLN to US dollars, $9 \%$ to euro, $5 \%$ to UAH, and $43 \%$ to PLN [1].

The term of legal employment has been extended to 9 months from 01/01/2018 in Poland. They sought for better control the work of foreigners by introducing seasonal work permits, which will be applied mainly in agriculture and tourism. Oldies will issue such permits to foreigners, provided that the salary is not lower than that offered to other employees in the same position, as well as if there is a confirmation that it was not possible to employ anyone from the local labor market. According to forecasts, Ukrainian workers in Poland will exceed 2 million ppls in 2018.

Fixed rapid growth of volumes of intellectual labor migration in last years. Poland's interest in skilled migrants (professionals, teachers, doctors, IT workers) and has a manifestation in the simplified way of their 
employment. For example, university professors, scholars, and foreign language teachers do not require a work permit. A significant need for medical workers in Poland is due to the active emigration of their doctors. The country had the smallest number of physicians across the EU per $1,000 \mathrm{ppl}$ in 2010. The frequency of appeals by Polish to doctors is higher than the average indicator in Europe (6.6 times a year).

The largest number of students from Ukraine is among all foreigners studying in Poland. Pragmatic Ukrainian entrants consider education in Poland prestigious and promising. The University of Warsaw leads the University of Warsaw (it ranked the top Polish universities after 2017) in the current ranking of Polish universities, in terms of probable earnings after graduation. The average salary of those who studied here is 5.5 thousand PLN [10]. The most modest salaries of masters of Polish universities graduates in Bialostok, Riashev and Kielce are 2.7 times higher than the average salary in Ukraine (more than 3,000 PLN).

The salaries of graduates (and Ukrainian ones) are significantly differentiated by the chosen specialty. The highest salaries can be expected by graduates of the faculties related to IT, banking and light industry. The most modest salaries in industries related to services for the population, science and education.

The volumes of Ukrainian student migration to Poland are increasing every year, and this is also part of the Polish strategy for tackling overdue problems. Now, even those students who are not the owners of the Polish Card can apply for scholarships in Poland. A lot of scholarship programs and grants for this purpose have been created, as follows: free study program "Study tours to Poland"; "Gaude Polonia" grant; program "Teraz Wrocław"; Stypendium im. L. Kirkland; student exchange program Erasmus +; Stypendium im. K. Skubiszewski; Stypendium im. Stanisław Banach; scholarship program "Thesaurus Polonia" and others. 
The border trading is an important factor in the social development of the Ukrainian-Polish border territories. Between 100 and 200 thousand Ukrainians were involved in border trade [11]. The border provides diversification of incomes, and demotivate work in Ukraine with earning $\$ 20-\$ 50$ for one trip to Poland [11]. Hryvnia devaluation introduced from 01.01.2018 created the new customs payments in Ukraine and adjust the employment and living standards of the Ukrainian borderland. The adoption of the Trade Bargaining Act in Poland as of 1.03.2018 limits trade to official holidays and, at the same time, the functioning of Polish business in neighboring territories of Ukraine. Private procurement annually made 12$16 \%$ of foreign trade turnover between countries.

The Polish Office for Foreigners Affairs reports that the number of Ukrainians with a permanent residence permit in Poland as of the beginning of 2018 increased by 4.5 times to 127 thousand compared to 2013 [12]. 625 Ukrainian citizens appealed to the Office to provide them with international protection in 2008, and in 2016 they were twice as previous. During the years 2008-2017 about 15,000 Ukrainians became citizens of Poland. Accommodation in Poland was also interested for citizens of Belarus (mostly for permanent residence), India (most for temporary stay), China and Vietnam. Within the framework of the Swiss-Polish Cooperation Program, the Office presents a portal - Migracje.gov.pl, concerning migration to Poland.

The researchers state the formation of the Ukrainian diaspora in Poland, at the same time, ethnic Ukrainians who live on their ethnic lands do not consider the diaspora. The ethnic Ukrainians in Poland are the most numerous groups formed in the Warmian-Masurian, Western Pomeranian and Lower Silesian area and presents the Association of Ukrainian Poles (OUU), which covers about 7,000 members [13]. The PMU form ten regional divisions and seven independent circles in the largest cities of 
Poland. Peter Timy, the chairman of the PMU reported at the international conference "UWC in 50 years and beyond: the European context" (28.08.2017, Lviv) in Poland at that time was: 48 thousand people of Ukrainian origin on a permanent basis; one million workers from Ukraine; 40 thousand Ukrainian students; up to seven thousand Ukrainian children who are not covered by Ukrainian language and literature education, which creates a solid foundation for accelerated assimilation.

Reorientation of Ukrainian private investments to Poland was recorded. Ukrainians bought in Poland $22 \%$ of the living space acquired by foreigners in 2016. The purchase of residential space by Ukrainians increased by 35$40 \%$ in $2014-2015$ and by $81 \%$ in 2016 . Ukrainians are buying housing in Warsaw, Gdansk, Krakow, Wroclaw, Poznan for their own needs and also for investment [14]. Polish banks simplify the procedure for opening bank accounts to Ukrainians providing simultaneous language support. Ukrainians crossing the border with Poland in 3/4 of the cases do not go further than $50 \mathrm{~km}$ and live also near the border, demonstrating typical shopping tourism. Ukrainian citizens spend less on Germans in general, but during their visit to Poland, an average citizen of Ukraine spends on average 730 PLN (\$ 195), while a citizen of Germany - only 500 PLN (134 \$) [15].

Conclusions. The conducted research gives grounds to state the progress of extremely negative tendencies in Ukraine, which are especially expressive against the background of similar processes in Poland. The Polish government analyzed the results of demographic projections and on this basis actively solves the problem of labor shortages, including with the help of Ukrainian workers. Simplified employment of Ukrainian intellectuals in Poland has exacerbated the outflow of well-educated specialists from Ukraine, and significantly weakens its economy. Due to the significant growth of Ukrainian students in Poland its educational system is 
sustenance and the Ukrainian educational system collapses. But it also creates problems for the Polish economy by increasing workload and creating social and cultural problems. Improvement of the situation is possible due to the implementation of a system of economic measures aimed at the settlement of the migration flows "Ukraine-Poland" in a mutually beneficial direction for both countries.

\section{References:}

1. Shevchuk, L., Labinska G. (2016). Mihratsiini vyklyky dlia krain Zakhidnoi Yevropy [Migration Challenges for Western Europe]. Zbirnyk dopovidei Mizhnar. nauk.-prakt. konferentsii "Mihratsiia mizh Ukrainoiu ta YeS: vyklyky bezvizovoho rezhymu". Lviv. 15 hrudnia 2016 r. 126-132. [in Ukrainian].

2. Kompleksnyi demohrafichnyi prohnoz Ukrainy na period do 2050 roku [Comprehensive demographic forecast for Ukraine up to 2050] (2006). Za red. chl.-kor. NANU, prof. E.M.Libanovoi., Kyiv, Ukrainskyi tsentr sotsialnykh reform, 2006. 138 p. [in Ukrainian].

3. Malinovska, O. (2015). Ukrainsko-polskyi mihratsiinyi korydor: osoblyvosti ta znachennia [Ukrainian-Polish Migration Corridor: Peculiarities and Importance]. Zbirnyk materialiv mizhnarodnoho sympoziumu "Mihratsiia u kryzovykh umovakh: ukrainsko-polskyi kontekst" (3 veresnia 2015 r.)., Lviv, Vydavnytstvo Lvivskoi Politekhniky. 58-74 [in Ukrainian].

4. Chmielewska, I., Dobrochek, G., Panuciak A. (2018). Obywatele Ukrainy pracujący w Polsce - raport badania [Citizens of Ukraine working in Poland - study report]. Departament Statystyki NBP. Warszawa, 2018 r. https://www.nbp.pl/aktualnosci/wiadomosci_2018/obywatele-Ukrainypracujacy-w-Polsce-raport.pdf [in Polish].

5. Shapran V. (2018). Rvanut ly ukrayntsy v Hermanyiu za zarplatamy 50100 tysiach hryven y kak эto udaryt po ekonomyke Ukrayny [Do Ukrainians 
rush to Germany for wages of 50-100 thousand hryvnias and how it will hit Ukraine's economy]. https://newsone.ua/news/economics/otkrytie-rynkatruda-v-hermanii-naskolko-bystro-ukraintsy-rynutsja-za-zarplatoj-v-2800evro.html [in Russian]. (2019, February, 27).

6. World Population to 2300 (2004). United Nations. Department of Economic and Social Affairs. New York. 2004. 240 p.

7. World Population Prospects, The 2017 Revision. Key Findings and Advance Tables (2017). United Nations. New York. 53 p

8. Ukraina: Prohnoz rozvytku produktyvnykh syl [Ukraine: Forecast for the development of productive forces] (1998). Kyiv. RVPS Ukrainy, 1998., Tom II (dodatky). 119 p. [in Ukrainian].

9. V yakykh krainakh Yevrosoiuzu ukraintsiam platiat naibilshe? [In which countries of the European Union Ukrainians are paid the most?] (2018). http://a-de.in.ua/link.php?url=Де-в-ЄС-українцям-платять-найбільше [in Ukrainian]. (2019, April, 27). [in Ukrainian].

10. Po jakim polskim uniwersytecie zarabia się najwięcej? Jest mocny lider [Which Polish university earns the most? There is a strong leader] (2018). https://tvn24bis.pl/z-kraju,74/zarobki-absolwentow-polskichuniwersytetow,748544.html [in Polish]. (2019, April, 27).

11. Official website of the State Border Guard Service of Ukraine. https://dpsu.gov.ua/ (2019, April, 27).

12. Urshąd do Spraw Cudzoziemców [Office for Foreigners]. https://udsc.gov.pl/ (2019, April, 27).

13. Official page of the Association of Ukrainians in Poland. http://www.oup.ukraina.com.pl/ (2019, April, 27).

14. Glovatsky Y. (2018). Hto kupuye pol`s'ku neruxomist’? Zvisno, ukrayinci [Who buys Polish real estate? Of course - Ukrainians] (2018). https://wz.Iviv.ua/article/367093-khto-kupuie-polsku-nerukhomist-zvisnoukraintsi (2019, April, 27). [in Ukrainian]. 
15. Ukraintsi vytrachaiut u Polshchi bilshe hroshei, nizh nimtsi [Ukrainians spend more money in Poland than the Germans] (2016). https://portal.Iviv.ua/news/2016/01/02/ukrayintsi-vitrachayut-u-polshhibilshe-groshey-nizh-nimtsi (2019, April, 27). [in Ukrainian]. 